\title{
Vegetation coverage in hydrographic basins in the central region of the State of São Paulo, Brazil
}

\author{
Bertini, MA. ${ }^{*}$, Fushita, AT. ${ }^{b}$ and Lima, MIS. ${ }^{c}$ \\ aPrograma de Pós-Graduação em Ecologia e Recursos Naturais, Universidade Federal de São Carlos - UFSCar, \\ Rodovia Washington Luís, km 235, CP 676, CEP 13595-605, São Carlos, SP, Brazil \\ 'Laboratório de Análise e Planejamento Ambiental, Universidade Federal de São Carlos - UFSCar, \\ Rodovia Washington Luís, km 235, CP 676, CEP 13595-605, São Carlos, SP, Brazil \\ 'Departamento de Botânica, Centro de Ciências Biológicas e da Saúde, Universidade Federal de São Carlos - UFSCar, \\ Rodovia Washington Luís, km 235, CP 676, CEP 13595-605, São Carlos, SP, Brazil \\ *e-mail: mbertini@ufscar.br
}

Received: November 13, 2013 - Accepted: March 13, 2014 - Distributed: August 31, 2015

(With 3 figures)

\begin{abstract}
Vegetation coverage can be inappropriately used, especially in the absence of proper planning, and can result in a reduction of the occupied area. Demographic and economic alterations are factors that contribute to the degradation of vegetation coverage in landscape units. In addition, because vegetation is essential for protection of recharge areas in aquifers, the fragmentation of habitats in hydrographic basins causes changes in climate temperature, soil erosion, eutrophication, and siltation of watercourses. This study analyzed the vegetation coverage from the municipality of São Carlos, State of São Paulo (SP) to assess the environmental quality of water resources in the hydrographic basins and sub-basins, in the Guarani Aquifer System. The vegetation coverage was analyzed in three scales: municipality, Hydric Resource Management Units (UGRHIs), and hydrographic sub-basins based on map overlapping from the LAPA/UFSCar Digital Cartographic Collection and visual interpretation of LANDSAT 5, TM sensor, Path 220, row 075 on satellite images. The municipality of São Carlos has vegetation coverage of $31,776.4$ hectares, in which $57 \%$ is classified as preserved vegetation typology, and $58 \%$ is over the Guarani aquifer recharge area. The vegetation coverage with savannas, riparian forests, and mesophyll forests represented $28 \%$ of the total studied area and is located over $28.3 \%$ of the Guarani aquifer recharge area extension. The Permanent preservation areas (PPAs) represent $21.6 \%$ of the total vegetation coverage with $51 \%$ of it being vegetated. The municipality has a total of 686 springs (Topographic maps of IBGE, escale 1:50,000) distributed on an average of 60 springs per $\mathrm{km}^{2} ; 40 \%$ of these are protected by vegetation.
\end{abstract}

Keywords: sub-basins, vegetation coverage, springs, Environmental Protection Areas.

\section{Cobertura vegetal nas bacias hidrográficas na região central do Estado de São Paulo, Brasil}

\begin{abstract}
Resumo
Alterações demográficas e econômicas são fatores que contribuem para a degradação da cobertura vegetal em unidades de paisagem. Além disso, a vegetação é essencial para a proteção de áreas de recarga de aquíferos. A fragmentação do habitat provoca mudanças climáticas locais, a erosão dos solos, a eutrofização e assoreamento dos cursos de água. Assim, o conhecimento sobre a hidrologia , flora e fauna de corpos d'água são essenciais para as estratégias conservacionistas. Este estudo analisou a cobertura vegetal do município de São Carlos, Estado de São Paulo (SP) para avaliar a qualidade ambiental dos recursos hídricos nas bacias hidrográficas e sub-bacias hidrográficas do Sistema Aquífero Guarani. A cobertura vegetal foi analisada em três escalas - municipal, Unidades de Gerenciamento de Recursos Hídricos (UGRHIs) e sub-bacias hidrográficas - com base no mapa de sobreposição da Coleção Cartográfica Digital LAPA/UFSCar e na interpretação visual de imagens LANDSAT 5 TM sensor, caminho 220, linha 075 no satélite imagens. O município de São Carlos tem cobertura de vegetação em 31.776,4 hectares, dos quais 57\% são classificados como tipologia de vegetação preservada e 58\% está sobre a área de afloramento do Aquífero Guarani. A cobertura vegetal, constituída por cerrados, florestas ciliares e florestas mesófilas representou $28 \%$ do total da área estudada e cobre $28,3 \%$ da extensão da área de recarga do Aquífero Guarani. As áreas de preservação permanentes (APPs) representam 21,6\% da cobertura total de vegetação, com 51\% de área vegetada. O município tem um total de 686 nascentes (Cartas topográficas do IBGE, escala 1:50.000) distribuídas em uma média de 60 molas por km², 40\% deles estão protegidos por vegetação.
\end{abstract}

Palavras-chave: sub-bacias, cobertura vegetal, nascentes, Áreas de Proteção Ambiental. 


\section{Introduction}

The vegetation at the margins of water bodies around springs and in wetlands are known as riparian forests; that avoid erosion processes and siltation in watercourses (Pinto et al., 2005) by acting directly on the hydrological and terrestrial dynamics of the hydrographic basin. Aquifers, which represent large subterranean freshwater reservoirs, become increasingly important when surface waters from rivers and streams gradually lose their quality.

The conservation of preserved areas and recovery of vegetation coverage in places where they are degraded must be considered in environmental studies because vegetation plays important environmental functions in combating soil erosion that results from the impact of rainwater and harmful effects of pollutants (Goulart et al., 2012). Moreover, vegetation is essential to protect recharge areas in aquifers.

Environmental management actions directed to a hydrographic basin area must observe the natural characteristics of a particular area under planning, thereby ensuring the conservation and sustainable use of natural resources, and must be performed or mediated by the Government (Pires et al., 2002). Thus, understanding the concept and using the approach per hydrographic basins and sub-basins becomes relevant especially for managers and researchers.

This approach allows for a systematic identification and monitoring of relationships between anthropic actions and biotic and abiotic factors, enabling the preparation of suggestions to mitigate environmental impacts and ensure the sustainable use of natural resources (Leonardo, 2003; Mosca, 2003).

This study addressed the questions: What is the status of vegetation coverage and hydrographic basins in the municipality of São Carlos, located in the central region of the State of São Paulo? Are riparian vegetation areas and springs protected in this municipality? Does the existing vegetation coverage protect the aquifer?

Based on the presented conceptions and guidelines, data on vegetation coverage from the municipality of São Carlos, State of São Paulo (SP) were collected, organized, and analyzed; moreover, the interrelations of the existing forest remnants in the study area with the environmental quality of water resources in the hydrographic basins and its sub-basins were analyzed in the Guarani Aquifer System to be used as indicators for planning occupation and land uses.

\section{Material and Methods}

\subsection{Area of study}

The municipality of São Carlos is located in the central region of the State of São Paulo, between the coordinates $47^{\circ} 30^{\prime}$ ' and $48^{\circ} 30^{\prime} \mathrm{W}$ and $21^{\circ} 30^{\prime}$ and $22^{\circ} 30^{\prime} \mathrm{S}$. It has a total population of 221,950 inhabitants and a territorial occupation area of $1,137.30 \mathrm{~km}^{2}$. The rural area covers
$1,057.06 \mathrm{~km}^{2}$ with a population of 8,889 inhabitants (IBGE, 2010).

This area is located in two Units of Water Resources Management: Tietê-Jacaré Basin and Mogi-Guaçu Basin (Pugliese et al., 2012). The municipality has lower drainage density of rivers and streams ranging from 0.6 to $1.7 \mathrm{~km} / \mathrm{km}^{2}$ due to permeability and slope average ranging from $0.1 \%$ to $22.4 \%$.

The municipality of São Carlos is located in the Guarani Aquifer System (GAS), over shallow and deep subsurface water springs, within the range of three aquifers: Botucatu (Botucatu/Piramboia), Itaqueri, and Serra Geral. These aquifers may be free or confined by layers of basaltic rocks and are mainly resulting from the Serra Geral Geological formation (Perroni and Wendland, 2008).

According to Soares et al. (2003), the original vegetation composition in the municipality of São Carlos was comprised of $27 \%$ of savanna (savanna sensu stricto, short-shrub savanna, and wet meadows), 16\% of arboreal savanna, $55 \%$ of semi deciduous and riparian forest, and 2\% of semi-deciduous forests with Araucaria angustifolia. The same authors found that the vegetation coverage in this area was quite fragmented and impoverished at the time of their research, showing predominantly savanna with different physiognomies, seasonal semi deciduous forest, riparian forest, and vegetation in initial regeneration phase with very heterogeneous characteristics due to climatic and soil conditions or human interference.

\subsection{Methodological procedures}

The analysis of existing remnants in the municipality of São Carlos considered the hydrographic basin approach in three levels: the landscape in the municipality of São Carlos, landscape of the basin regarding the division of the territory in compartments in which they are inserted in the Mogi-Guaçu Basin and Tietê-Jacaré Basin, and landscape of the ten major hydrographic sub-basins in the main rivers in the municipality: Guabirobas, Mogi-Guaçu, Araras, Cabaceiras, Quilombo, Chibarro, Monjolinho, Pântano, Jacaré-Guaçu, and Feijão (Figure 1).

The MAPINFO software was used for the physical diagnosis of hydrographic basins. The thematic maps (on a scale of 1:50,000) were built based on the database from the Digital Cartographic Collection in the Analysis and Environmental Planning Laboratory at the Federal University of São Carlos - LAPA/UFSCar.

Occupational typologies were delimited based on satellite images from the LANDSAT 5 TM sensor obtained at the National Institute for Space Research (INPE), path 220, row 075, on September 19, 2011, in false-color composition of bands 5 (red channel), 4 (green), and 3 (blue) with pixel resolution at $30 \mathrm{~m}$, and contrasted by histogram equalization in each channel. The satellite image was recorded based in information contained in the cartographic base of the study area, composed by the articulation of Araraquara (IBGE, 1971a), Descalvado (IBGE, 1971b), Ibaté (IBGE, 1971c), Luís Antônio (IBGE, 1971d), Porto Pulador (IBGE, 1971e) and São Carlos 

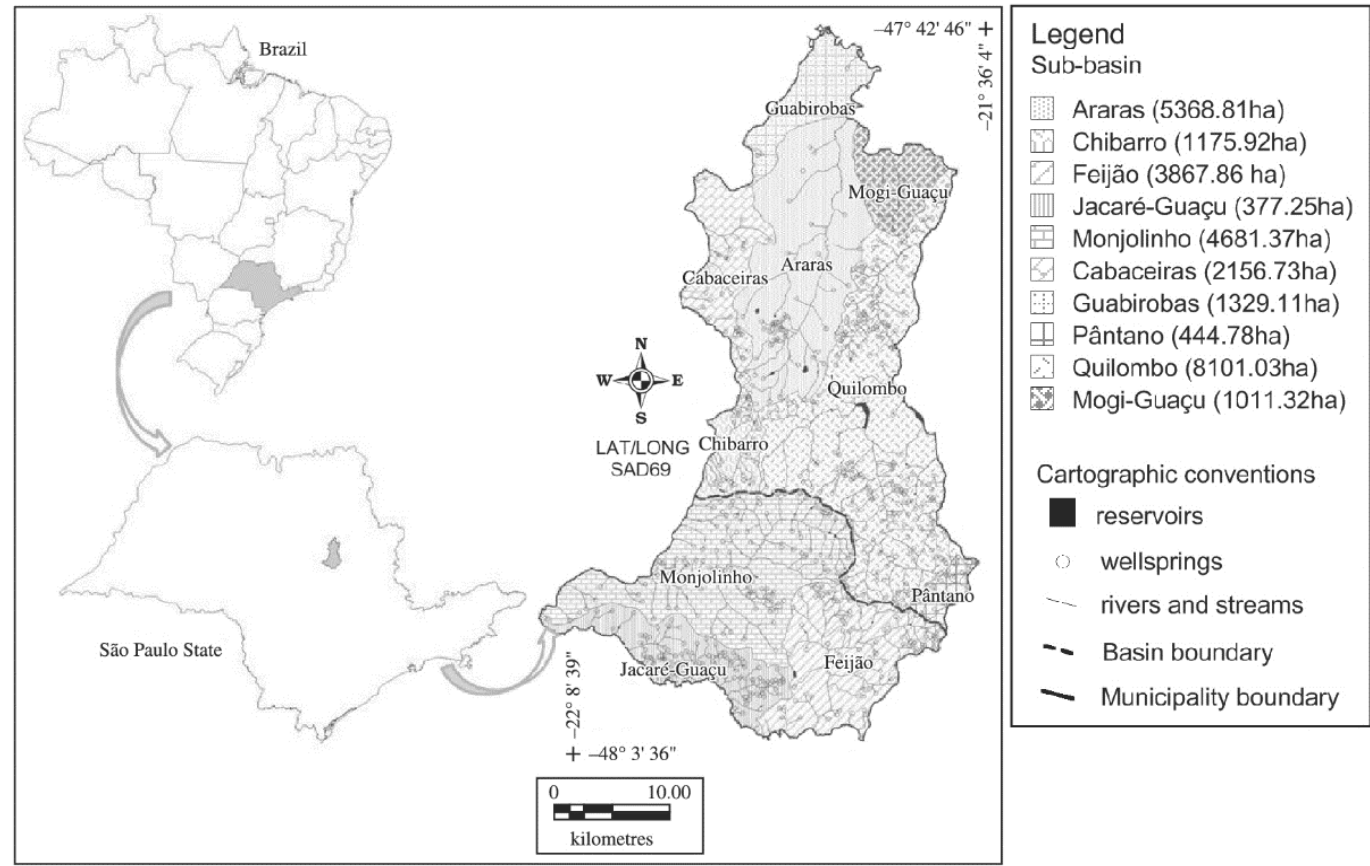

Figure 1. Mogi-Guaçu and Tietê-Jacaré UGRHIs, and their sub-basins.

(IBGE, 1971f), as well as visual interpretation of the vegetation coverage typologies.

The preliminary demarcations of vegetation fragments were performed for the characterization of vegetation coverage in the municipality of São Carlos, provided by the Coordination of Biodiversity and Natural Resources (CBRN)/Environmental Secretary of the State of São Paulo/São Carlos (CETESB). These demarcations were obtained during the execution of supervisory assessments in annotated areas for monitoring vegetation coverage evolution in the municipality and region. This information was supplemented with the visual interpretation of satellite images through the software MAPINFO 10.0 and verified (for type of vegetation coverage) by using Google Earth, 2012 release.

Vegetation coverage was classified in five types: 1. conserved (remnants of savanna, mesophyl forests, riparian vegetation); 2 . regenerating (in early succession stages); 3. mixed (sets of interconnected fragments by small deforested areas - pastures, barns); 4. potential for recovery (susceptible to anthropic occupation), and 5. green areas within the city limits. The division into sub-basins enabled the production of a map with the distribution of vegetation according to this classification.

The analysis of fragments by size (area) was based on Laurence et al. (1997), which defined three categories of fragments according to the perception of organisms and species. In this study, four categories were established: Class I $(0 \leq x<10$ ha), Class II $(10 \leq x<20$ ha), Class III $(20 \leq \mathrm{x}<275$ ha), and Class IV (275 $\leq \mathrm{x}<1,400$ ha).
The information used for map composition, showing recharge areas in the aquifer, were obtained from studies conducted by the Environmental Sanitation Technology Company of the State of São Paulo (CETESB) linked to the Environmental Secretary of the State of São Paulo. The analysis of the influence of vegetation coverage on the GAS recharge areas was performed using the vegetation coverage information overlaid with the map of geological formations (IPT, 1981).

The thematic maps of the permanent preservation areas and wellsprings (IBGE, 1971a-f) were overlaid with the vegetation coverage map, which provided quantitative data that were summed and later used to calculate the percentage of PPAs and wellsprings considering the sub-basin as management units.

The characteristics of vegetation coverage in the hydrographic sub-basins of São Carlos were evaluated by the Genebrino or Distantial method adapted for this case study by setting thresholds for the average between the best and worst situations encountered among the sub-basins in the municipality of São Carlos.

This method classifies the empirical value that is the most current value found according to their distance from the best possible situation. The results were divided into five ranges of better or worse condition: 0 to $20 \%$ (bad), 20 to $40 \%$ (regular), 40 to $60 \%$ (good), 60 to $80 \%$ (great), and 80 to $100 \%$ (excellent) (IPPUC, 2010). The indicators permeated all the study and consisted of the vegetation coverage percentage in the sub-basins, wellsprings, PPAs, recharge areas in the Guarani aquifer, and number of forest fragments. 


\section{Results}

\subsection{Typologies of vegetation coverage}

In 2012, the vegetation coverage in the municipality of São Carlos (CV-São Carlos) expanded over 31,776.4 hectares ( $28 \%$ of the total area); of these, $19,561.7$ hectares $(61.6 \%$ of the total area) were located in UGRHI- Mogi-Guaçu and $12,214.7$ hectares (38.4\% of the total area) in UGRHI- TietêJacaré. The typology of preserved vegetation represented $57 \%$ of the total area in the CV-São Carlos, and $38.9 \%$ of areas considered mixed.

The Jacaré-Guaçu sub-basin presents the lowest percentage of degradation of vegetation coverage and the highest percentage of preserved vegetation, whereas the Feijão sub-basin presents the highest level of degradation and the highest percentage of mixed vegetation among the ten hydrographic sub-basins in the municipality of São Carlos (Table 1).

The percentage of regenerating vegetation ranged from 0.1 to $8.2 \%$ in the sub-basins. The Monjolinho sub-basin, where the urban perimeter of the municipality occupies the largest area, has the highest percentage of these typologies among all other sub-basins, which demonstrates a concern for vegetation recovery in the landscape unit.

We observed that the percentage of area occupied by the preserved vegetation typology was high; however, it is restricted to basins with predominantly agricultural use (Table 1).

A total of 546 forest remnants were recorded in the municipality of São Carlos where 389 belong to Class I, 41 to Class II, 101 to Class III, and 15 to Class IV. A similar trend in the distribution of fragments by class sizes was observed when the UGRHIs were analyzed separately.

\subsection{Categories of vegetation coverage}

Out of the total number of fragments in the municipality, 429 belong to UGRHI - Mogi-Guaçu, among which, 311 belong to Class I and 11 to Class IV (largest size).
UGRHI - Tietê-Jacaré has three sub-basins and concentrates a smaller number of fragments relative to UGRHI - Mogi-Guaçu; this unit has a total of 118 fragments, 78 of which belong to Class I, 25 to Class III, and 4 to Class IV (largest size).

Fragments belonging to Class I (112) were predominant among the 154 surveyed in the Quilombo sub-basin. Five fragments $(25.8 \%$ of the total of preserved remnants in UGRHI - Mogi-Guaçu) belong to Class IV (largest size). The stream in the Araras sub-basin also stood out with a total of 135 fragments, with a predominance of 102 belonging to Class I and 3 to Class IV (12.5\% of the total of preserved remnants in the same basin). The Guabirobas, Mogi Guaçu, and Pântano sub-basins did not present fragments belonging to Class IV.

Fragments was surveyed in the Monjolinho sub-basin with a predominance of fragments belonging to Class I (44 fragments). Two fragments $(11.2 \%$ of the total of preserved remnants in UGRHI - Tietê-Jacaré) belong to Class IV (largest size). The Feijão sub-basin presented a total of 36 fragments with a predominance of 26 belonging to Class I and one belonging to Class IV ( $5 \%$ of the total of preserved remnants in the same basin). The Jacaré-Guaçu sub-basin totaled 15 fragments, with eight belonging to Class I and one to Class IV.

\subsection{Vegetation coverage in recharge areas in the Guarani aquifer}

The municipality of São Carlos has $58 \%$ of its territory in the recharge area of the GAS, also known as recharge area, of which, 28.3\% present vegetation coverage (Figure 2).

UGRHI - Mogi-Guaçu has $37.8 \%$ of recharge areas in the GAS, $61.6 \%$ of confined areas between basalt layers GAS, and $63.5 \%$ of vegetation coverage, while UGRHI Tietê-Jacaré has $20.3 \%$ of recharge area, $38.4 \%$ in confined areas, and $36.5 \%$ of vegetation coverage.

The UGRHI - Mogi-Guaçu sub-basins presented the following panorama: the two sub-basins with the largest

Table 1. Classification of types of vegetation coverage in the hydrographic basins in the municipality of São Carlos (in hectares and percentages).

\begin{tabular}{|c|c|c|c|c|c|c|c|c|c|}
\hline \multirow[b]{2}{*}{ Sub-basins } & \multicolumn{2}{|c|}{ conserved } & \multicolumn{2}{|c|}{ mixed } & \multicolumn{2}{|c|}{ regenerating } & \multicolumn{2}{|c|}{$\begin{array}{l}\text { potential for } \\
\text { recovery }\end{array}$} & \multirow{2}{*}{$\begin{array}{c}\text { Total per } \\
\text { sub- basin* }\end{array}$} \\
\hline & ha & $\%$ & ha & $\%$ & ha & $\%$ & ha & $\%$ & \\
\hline Araras & $2,640.40$ & 49.2 & $2,480.17$ & 46.2 & 122.18 & 2.3 & 126.06 & 2.3 & $5,368.81$ \\
\hline Cabaceiras & $1,311.69$ & 60.8 & 772.91 & 35.8 & 51.84 & 2.4 & 20.29 & 0.9 & 21,573 \\
\hline Chibarro & 652.69 & 55.5 & 474.02 & 40.3 & 38.37 & 3.3 & 10.84 & 0.9 & $1,175.92$ \\
\hline Feijão & $1,246.32$ & 32.2 & $2,466.70$ & 63.7 & 124.67 & 3.2 & 30.16 & 0.8 & $3,867.84$ \\
\hline Guabirobas & 475.10 & 35.7 & 756.31 & 56.9 & 28.30 & 2.1 & 69.40 & 5.2 & $1,329.11$ \\
\hline Jacaré-Guaçu & $3,571.70$ & 97.1 & 18.61 & 0.5 & 85.46 & 2.3 & 1.49 & 0.0 & $3,677.25$ \\
\hline Mogi-Guaçu & 515.23 & 67.5 & 458.45 & 30 & 1.71 & 0.1 & 35.93 & 3.6 & $1,011.32$ \\
\hline Monjolinho & $3,223.37$ & 68.8 & $1,014.17$ & 21.6 & 383.59 & 8.2 & 54.58 & 1.2 & $4,675.71$ \\
\hline Pântano & 298.15 & 67.0 & 139.51 & 31.4 & 0.86 & 0.2 & 6.25 & 1.4 & 444.78 \\
\hline Quilombo & $4,104.18$ & 50.8 & $3,808.76$ & 47 & 109.09 & 1.3 & 79 & 1.0 & $8,101.03$ \\
\hline Municipality & $18,038.83$ & $(57 \%)$ & $12,389.61$ & $(38.9 \%)$ & 946.07 & $(2.9 \%)$ & 434.00 & $(1.4 \%)$ & $31,808.51$ \\
\hline
\end{tabular}

* Public green areas were excluded from this analysis. 


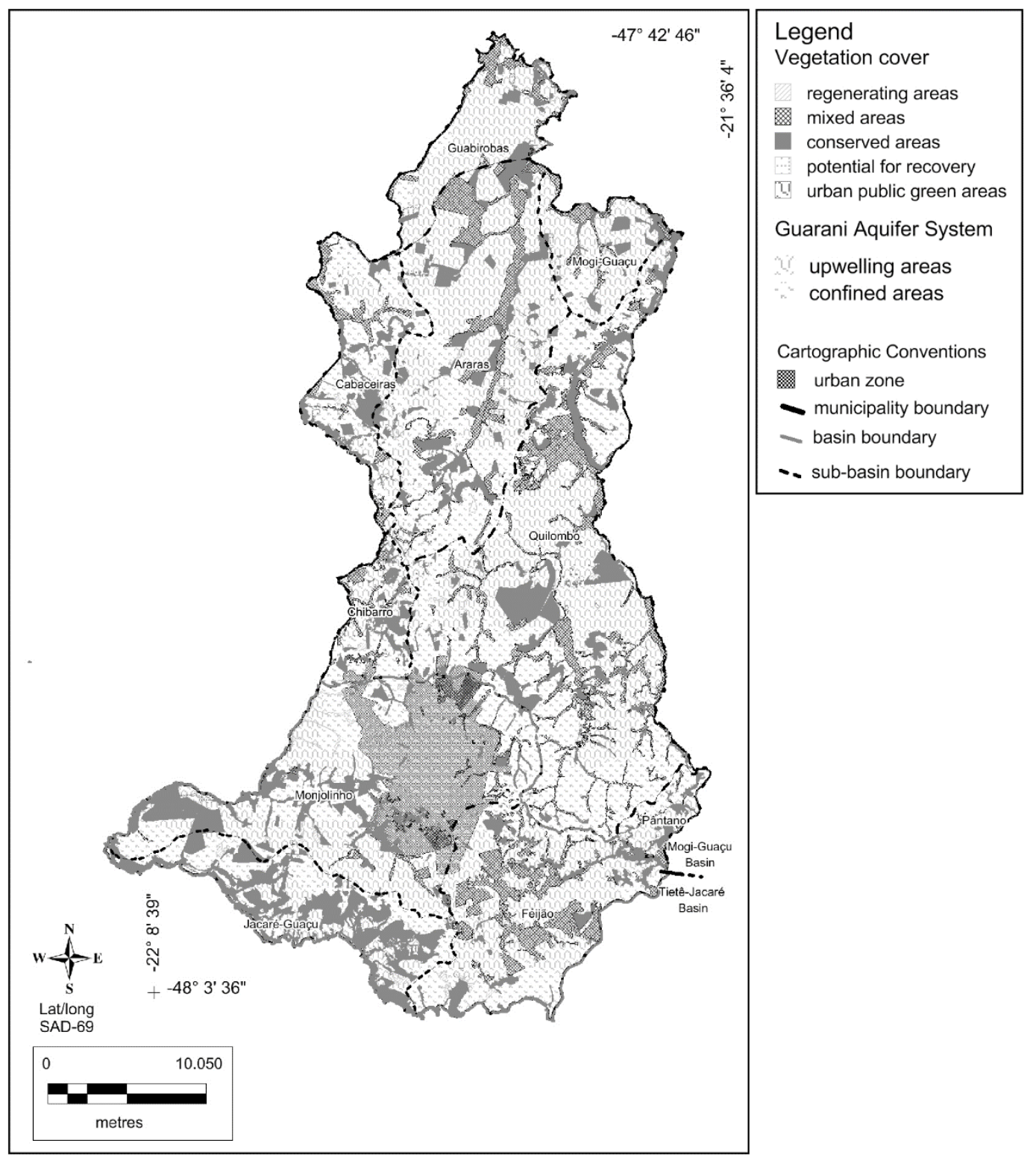

Figure 2. Vegetation coverage typology and the Guarani Aquifer System.

territories in the GAS recharge area were Guabirobas, with $89.4 \%$, and Mogi-Guaçu with $88 \%$ and $23 \%$ of vegetation coverage. However, Guabirobas had the lowest percentage of vegetation coverage (21\%).

The Chibarro sub-basin presented the highest percentage of vegetation coverage (40.3\%) with $58.2 \%$ in the recharge area; Cabaceiras presented the smallest recharge area (32\%) and $31 \%$ of vegetation coverage.

In the Tietê-Jacaré Basin, the Feijão sub-basin presented the largest territory in the recharge area (73\%) and $32.4 \%$ of vegetation coverage; the Jacaré-Guaçu presented vegetation coverage percentage $(49 \%)$ similar to the percentage of the recharge area (52\%), and the Monjolinho sub-basin presented the smallest recharge area (47\%) and smallest percentage of vegetation coverage (18.5\%).
3.4. Analysis of the Permanent Preservation Areas in the municipality of São Carlos

The municipality has a total of $6,877.80$ ha of PPAs (excluding springs) distributed in 10 hydrographic sub-basins where $3,528.04$ ha $(51.3 \%)$ present vegetation and $3,349.75$ ha $(48.7 \%)$ do not.

Mogi-Guaçu Basin has 57\% of PPAs and presented an average of $48.8 \%$ of vegetation coverage while Tietê-Jacaré Basin presented $43 \%$ of PPAs and $49.4 \%$ of vegetation coverage.

The Guabirobas sub-basin presented the least degraded PPAs in its territorial extension with $60.7 \%$ of vegetation coverage. The Pântano sub-basin presented the smallest vegetation coverage (33.2\%) (Table 2 ). 
Table 2. Percentage of Vegetable PPAs, Spring Areas and Spring Number of Mogi-Guaçu and Tiete-Jacaré UGRHIs.

\begin{tabular}{lcccc}
\hline & \% Vegetated PPAs & $\begin{array}{c}\text { \% Vegetable Spring } \\
\text { Áreas }\end{array}$ & $\begin{array}{c}\text { Spring Number } \\
\text { UGRHI - Mogi- } \\
\text { Guaçu }\end{array}$ & $\begin{array}{c}\text { Spring Number } \\
\text { UGRHI - Tietê- } \\
\text { Jacaré }\end{array}$ \\
\hline Araras & 58.2 & 53.8 & 52 & - \\
Cabaceiras & 40.9 & 64.5 & 31 & - \\
Chibarro & 47.7 & 35.3 & 34 & - \\
Feijão & 53.8 & 29.5 & - & - \\
Guabirobas & 60.7 & 100 & 3 & - \\
Jacaré-Guaçu & 56.2 & 59.3 & - & - \\
Mogi-Guaçu & 43.9 & 40.0 & 5 & - \\
Monjolinho & 38.1 & 32.1 & - & - \\
Pântano & 33.2 & 28.6 & 21 & - \\
Quilombo & 57.2 & 48.2 & 228 & \\
\hline
\end{tabular}

A significant portion of PPAs do not present vegetation coverage and are, therefore, environmentally vulnerable. The Pântano sub-basin presented $66.8 \%$ of PPAs without vegetation coverage, and the Guabirobas sub-basin has the smallest area without vegetation (39.2\%) (Table2).

\subsection{Analysis of areas with springs in the context of Permanent Preservation Areas.}

The municipality has a total of 686 wellsprings where $55 \%$ are without vegetation and environmentally vulnerable (Figure 1).

Mogi-Guaçu Basin has 374 springs (54.5\% of the total wellsprings), $26.4 \%$ of them with vegetation coverage. Tietê-Jacaré Basin has 312 springs $(45.5 \%$ of the total wellsprings), $18.5 \%$ of them with vegetation coverage (Table 2).

The sub-basins with springs with higher percentages of vegetation coverage in UGRHI - Mogi-Guaçu were Guabirobas, with $100 \%$ of protected wellsprings, and Cabaceiras, with $64.5 \%$, and Araras with $53.8 \%$. The sub-basins with the smallest percentages of vegetation coverage were Pântano with $28.6 \%$ and Chibarro with $35.3 \%$ (Table 2).

The sub-basin with the highest percentage of vegetation coverage in recharge areas in UGRHI - Tietê-Jacaré was Jacaré-Guaçu, with 59.3\%; Feijão showed the smallest vegetation coverage (29.5\%) (Table 2).

\subsection{Relative environmental quality index in the studied hydrographic sub-basins}

The Genebrino method described in the methodology allows the comparison of the percentage of vegetation cover between sub-basins. This method index highlighted the indicators that permeated the characterization of hydrographic basins in the municipality in relation to quality aspects of vegetation coverage based on the following analysis:

a) Percentage of areas with vegetation coverage: the Jacaré-Guaçu sub-basin was considered of excellent quality (100\% coverage). Conversely, the MogiGuaçu and Monjolinho sub-basins were rated as bad ( 0 to $20 \%$ ). The Chibarro sub-basin obtained good rating (48\%) and all the others were rated as regular; b) Percentage of springs with vegetation coverage: the Guabirobas sub-basin obtained excellent rating $(100 \%)$ while the Pântano and Feijão sub-basins received bad ratings with less than $1.3 \%$, and the Chibarro, Mogi-Guaçu, and Monjolinho were rated with less than $10 \%$ of quality. The Araras and Quilombo sub-basins received regular rating (20 to 40\%) and Jacaré-Guaçu received a good rating $(42.9 \%)$;

c) Percentage of PPAs with vegetation coverage: the Araras, Guabirobas, Quilombo, and JacaréGuaçu sub-basins obtained excellent ratings with indexes ranging from $83.5 \%$ to $100 \%$; the Feijão sub-basin obtained good rating (75\%), the Chibarro basin obtained good rating (53\%); the Pântano and Monjolinho sub-basins were rated as bad with indexes from 0 to $17.5 \%$; the remaining sub-basins were rated as regular;

d) Percentage of Guarani aquifer recharge areas with vegetation coverage: the Jacaré-Guaçu sub-basin was rated as excellent (100\%), Chibarro was rated as great (72\%), the Cabaceiras, Pântano, and Feijão sub-basins were rated as good, the Monjolinho and Guabirobas sub-basins were rated as bad, and all others as regular;

e) Percentage of forest fragments: the Quilombo and Araras sub-basins were rated as excellent. The Pântano, Guabirobas, Mogi-Guaçu, JacaréGuaçu, and Feijão sub-basins were rated as bad, with indexes ranging from 0 to $16.3 \%$; all others were classified as regular.

Thus, the overall Genebrino index in this municipality was $38.6 \%$, which is considered at a regular environmental satisfaction level. The index rated the Jacaré-Guaçu sub-basin as excellent in quality (index of 100\%), the Monjolinho and Mogi-Guaçu sub-basins as poor (indexes from 0 to 20\%), and all other sub-basins as regular (indexes ranging from 20 to $40 \%$ ) (Figure 3). 

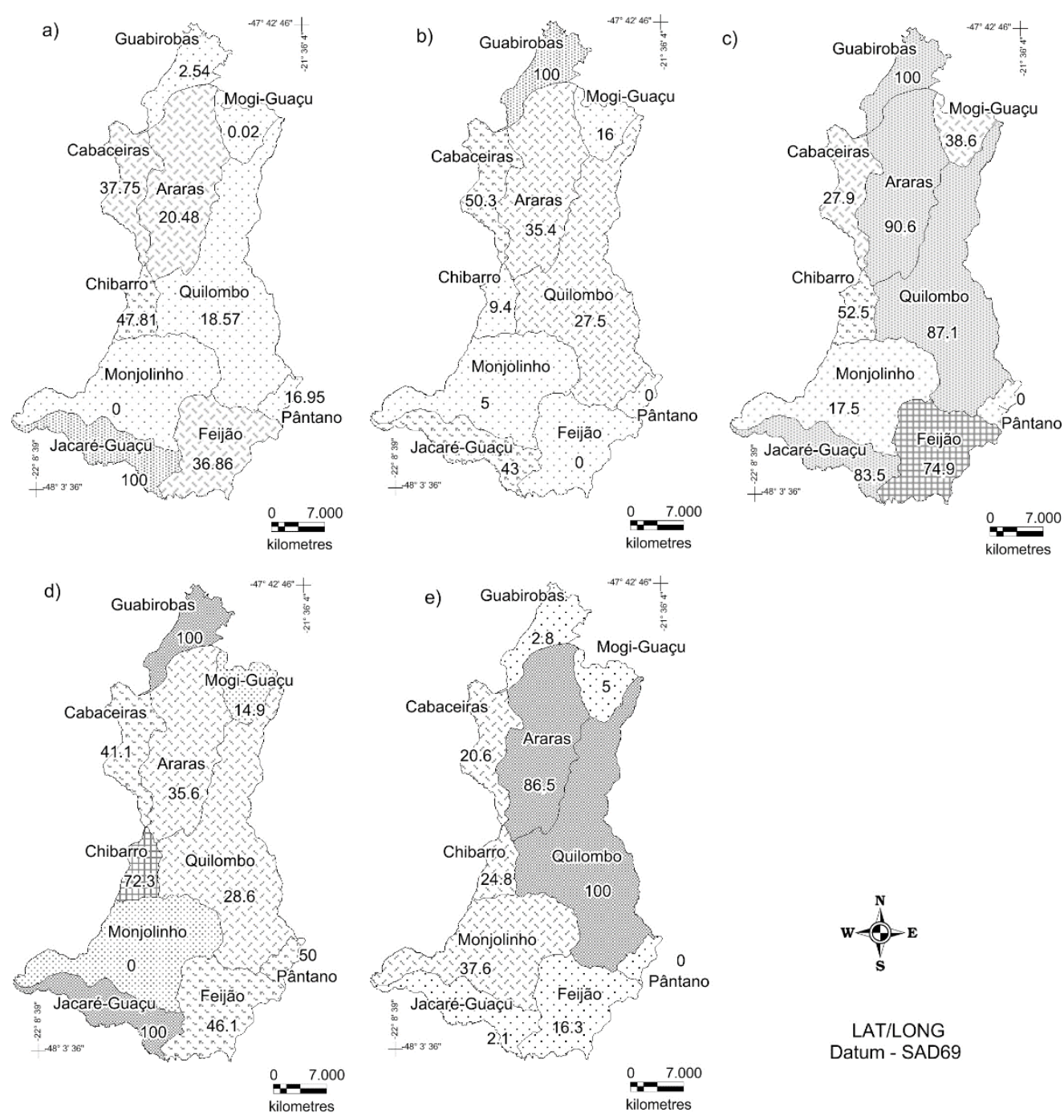

kilometres

\begin{tabular}{|ll|}
\hline a) Percentage of areas with vegetation coverage & Legend \\
b) Percentage of wellsprings with vegetation coverage & Genebrino Indexes \\
c) Percentage of permanet protected areas with vegetation coverage & 80 to 100 (excellent) \\
d) Percentage of Guarani Aquifer upwelling areas with vegetation coverage & 60 to 80 (great) \\
e) Percentage of forest fragments & 40 to 60 (good) \\
\hline
\end{tabular}

Figure 3. Genebrino indexes in the municipality of São Carlos.

\section{Discussion}

In 2012, the existing vegetation coverage considering the savannas, riparian forests, and mesophyl forests represents $28 \%$ of the total area in the studied municipality. The fragments of preserved, less degraded vegetation, identified in the total study area of 546 vary in size and may be distributed in four categories from 0 to 10 ha (389 fragments), 10 to 20 ha (41fragmentos), 20 to 275 ha (101 fragments), and 275 to 1,400 ha (15 fragments). The fact that the majority of the fragments fall in the first category demonstrates that interconnecting them and establishing ecological corridors could make them less vulnerable.
The fragments where vegetation is susceptible to anthropic occupation do not exceed $1.26 \%$ of the study area. The Guabirobas sub-basin has the highest percentage of such fragments, not exceeding 5.2\%. It is noteworthy that, in this sub-basin, we identified an increased environmental vulnerability in relation to their occupation considering that it has just $60.7 \%$ of PPAs with vegetation and numerous fragments of class I subjected to degradation by agricultural expansion; additionally, the area suffers with edge effects and decreased species richness due to its isolation.

In this study, the adaptation of the methodology described by Laurence et at. (1997) allowed the perception 
that fragments up to 20 ha represent $71.2 \%$ of the total area while the largest fragments (Class IV) represent only $2.7 \%$ of the total area.

The vegetation coverage of the hydrographic sub-basins in the municipality of São Carlos is distributed as a mosaic of fragments with different phytophysiognomic aspects in a succession of differentiated stages. This vegetation coverage suffered significant anthropogenic interference with urban and rural expansion.

Among the ten sub-basins in the municipality of São Carlos, Jacaré-Guaçu, Monjolinho, Pântano and Quilombo present the least degraded vegetation coverage based on the largest percentage of preserved remnants. The Guabirobas and Feijão sub-basins are in critical condition and lack concrete protection strategies.

Considering the hydro-geological conditions of GAS, $58 \%$ of the municipality is in recharge areas with only $28.3 \%$ of vegetation coverage, which consequently increase polluting activities. Thus, the protection of this system as a whole depends on a territorial planning of land use with actions aimed at the recovery and protection of vegetation coverage.

The Jacaré-Guaçu sub-basin is cited in the Director Plan for the municipality of São Carlos, under the Law number 13,691 from November 25, 2005, as an area of predominant agricultural use. This fact is of concern because this is the most protected sub-basin in the study area. In addition, it is located in the recharge area in the Guarani aquifer and could be subjected to impacts related to soil management, fertilization, and pesticides use, which would aggravate the aquifer situation.

The degradation of vegetation formations should not be discussed without considering their integration in the context of land use and occupation as the result of disorderly expansion of agricultural frontiers, or inadequate agricultural practices (Rodrigues and Gandolfi, 2004). The absence of vegetation leads to removal of large amounts of soil during rainy periods, with total amount removed dependent on soil composition, ground slope, and rain intensity. Vegetation mitigates the impact of water on soil through mechanisms that hamper the power of raindrops facilitating its infiltration into the soil with increasing porosity favored by the leaf decomposition (Branco, 1995). This factor contributes to the supply of groundwater in a uniform manner throughout the year (Tauk-Tornisielo et al., 1995).

The results from the permanent preservation areas demonstrate the low percentage of areas with vegetation in the ratio between territorial dimension and vegetation coverage; this coverage percentage is very low in several sub-basins as shown earlier, indicating environmental vulnerability of water bodies in almost all sub-basins in the municipality.

The Guabirobas sub-basin presents the greatest percentage of vegetation coverage in its PPAs (60.7\%); however, it is observed that the hydrographic network has lower drainage density compared to other sub-basins. Conversely, the Jacaré-Guaçu sub-basin has greater water density and a lower percentage of vegetation coverage $(56.2 \%)$ compared to the other sub-basins in the study area.

The sub-basins have a vegetation coverage deficit ranging from 39.2 to $66.7 \%$ for the PPAs with respect to protection of surface waters, and thus, they do not comply with the legal regulations imposed by the Brazilian Forest Code (Brasil, 1965).

The results obtained with the Genebrino method can be used as an important tool to understand the dynamics of municipality expansion and could contribute to the adoption of measures for conservation, recovery, and monitoring of sub-basins to increase the satisfaction indicator indexes for vegetation coverage.

The municipality of São Carlos has 686 springs, which represents an average of 60 springs per $\mathrm{km}^{2}$, and only $40 \%$ are protected by vegetation. The need for conservation and/or recovery of vegetation remnants and areas considered as environmentally vulnerable due to their proximity to water bodies or their topography is addressed in the Forestry Code (Brasil, 1965) and environmental municipal zoning policy through the Director Plan. However, a significant effort is still needed to ensure that the municipality meets this goal, although they are being proposed new forest code, still pending in Congress.

The Mogi-Guaçu Basin has the most compromised situation regarding vegetation coverage in the studied municipality.

In Tietê-Jacaré Basin, the Jacaré-Guaçu is the least compromised, and Feijão is the most compromised sub-basin.

Approximately half of the PPAs in the municipality of São Carlos require recovery measures.

Almost $72 \%$ of the recharge areas in the Guarani aquifer are compromised because of the low percentage of vegetation coverage and inadequate land use and occupation.

The Jacaré-Guaçu sub-basin has a Genebrino index of $100 \%$ in excellence for vegetation coverage while the Monjolinho and Mogi-Guaçu sub-basins present unsatisfactory ratings. All other studied sub-basins present regular quality indexes. Our results show that the studied indicators are relevant guiding tools in planning land use and occupation.

\section{Acknowledgements}

The authors are thankful to doctors José Eduardo dos Santos and João Juares Soares for suggestions in the study; to the graduate program in Ecology and Natural Resources; to the Laboratory of Analysis and Environmental Planning (UFSCar) for aid in the treatment of images and creation of maps; to the National Institute for Space Research for providing satellite images; to the forest engineer Victor Emanuel Giglio Ferreira from the Coordination of Biodiversity and Natural Resources (CBRN)/Environmental Secretary of the State of São Paulo/São Carlos, for information about the fragments with existing vegetation in the municipality; and to the Paula Souza Center by the granting partial severance from teaching activities to the first author. 


\section{References}

BRANCO, SM., 1995. Como se faz um deserto. In: BRANCO, SM. O meio ambiente em debate. 22nd ed. São Paulo: Moderna. p. 32-36.

Brasil, 1965. Lei n. 4.771 de 15 de setembro de 1965. Institui o novo Código Florestal Brasileiro. Diário Oficial da União, Brasília, 15 set.

GOULART, MP., CAMPOS, HCNS. and NEPOMUCENO, O., 2012. Tutela jurídica do Aquífero Guarani em Ribeirão Preto (Estado de São Paulo, Brasil). Boletín Geológico y Minero, vol. 123, no. 3, p. 389-399.

Instituto Brasileiro de Geografia e Estatística - IBGE., 1971a. Carta do Brasil. Araraquara SF-22-X-D-VI-4.. Rio de Janeiro: IBGE. Escala 1: 50.000 .

Instituto Brasileiro de Geografia e Estatística - IBGE., 1971b. Carta do Brasil. Descalvado SF-23-V-C-IV-4. Rio de Janeiro: IBGE. Escala 1: 50.000 .

Instituto Brasileiro de Geografia e Estatística - IBGE., 1971c. Carta do Brasil. Ibaté SF-23-V-C-IV-3. Rio de Janeiro: IBGE. Escala 1: 50.000 .

Instituto Brasileiro de Geografia e Estatística - IBGE., 1971d. Carta do Brasil. Luís Antônio SF-23-V-C-IV-2. Rio de Janeiro: IBGE. Escala 1: 50.000 .

Instituto Brasileiro de Geografia e Estatística - IBGE., 1971e. Carta do Brasil. Porto Pulador SF-23-V-C-IV-1. Rio de Janeiro: IBGE. Escala 1: 50.000 .

Instituto Brasileiro de Geografia e Estatística - IBGE., 1971f. Carta do Brasil. São Carlos SF-23-Y-A-I-1. Rio de Janeiro: IBGE. Escala 1: 50.000 .

Instituto Brasileiro de Geografia e Estatística - IBGE., 2010. Cidades. São Paulo - São Carlos. Rio de Janeiro: IBGE. Available from: $<$ http://cidades.ibge.gov.br/xtras/perfil.php?lang=\&codmun $=354890 \&$ search $=$ sao-paulo|sao-carlos $>$. Access in: 22 Aug. 2012 .

Instituto de Pesquisa e Planejamento Urbano de Curitiba - IPPUC., 2010. Análise de desempenho 1970 a 2009, controle ambiental e desenvolvimento sustentável. Coordenação de Maria Teresa Bonatto de Castro e Marília Isfer Ravanello. Curitiba: IPPUC. 69 p. Avaliação do Plano Diretor, no. 2.

Instituto de Pesquisas Tecnológicas - IPT, 1981. Mapa geomorfológico do Estado de São Paulo. São Paulo: IPT. Escala 1:1.000.000.

LAURENCE, W., BIERREGAARD, RO., GASCON, C., DIDHAM, RK., SMITH, AP., LYBAM, AJ., VIANA, VM., LOVEJOY, TE., SIEVING, KE., SITES, JW., ANDERSEN, M., TOCHER, MD., KRAMER, EA., RESTREPO, C. and MORITZ, C., 1997. Tropical Forest fragmentation:synthesis of a diverse and dynamic discipline. In LAURENCE, WF. and BIERREGAARD, RO. (Eds.). Tropical Forest remnants ecology, management and conservation of fragmented communities. Chicago: University of Chicago Press. p. 502-514.

LEONARDO, HCL., 2003. Indicadores de qualidade de solo e água para avaliação do uso sustentável da microbacia hidrográfica do rio Passo CUE, região oeste do Estado do Paraná. Piracicaba: Escola Superior de Agricultura Luis de Queiroz, Universidade de São Paulo. 121 p. Masters Dissertation in Forest Resources.

MOSCA, AAO., 2003. Caracterização hidrológica de duas microbacias visando a identificação de indicadores hidrológicos para o monitoramento ambiental de manejo de florestas plantadas. Piracicaba: Escola Superior de Agricultura Luis de Queiroz" Universidade de São Paulo. 96 p. Masters Dissertation in Forest Resources.

PINTO, LVA., BOTELHO, SA., OLIVEIRA-FILHO, AT. and DAVIDE, AC., 2005. Estudo da vegetação como subsídios para propostas de recuperação das nascentes da bacia hidrográfica do Ribeirão Santa Cruz, Lavras, MG. Revista Árvore, vol. 29, no. 5, p. 775-793. http://dx.doi.org/10.1590/S0100-67622005000500013.

PIRES, JSR., SANTOS, JE. and LE, ME., 2002. A utilização do conceito de bacia hidrográfica para a conservação dos recursos naturais. Conceito de bacias hidrográficas: teoria e aplicações. Ilhéus: Editus. p. 17-35.

PERRONI, JCA. and WENDLAND, EC., 2008. Avaliação das condições de ocorrência e explotação do Sistema Aquifero Guarani em São Carlos - SP. Águas Subterrâneas, vol. 22, no. 1, p. 13-24.

PUGLIESE, E., ALMEIDA LEITE, WCD., CASTRO, MCAAD. and SCHALCH, V., 2012. Exigências para o licenciamento ambiental de áreas para a implantação de aterros sanitários no Brasil: a experiência do município de São Carlos, SP. In VII Congreso de Medio Ambiente de la AUGM, 2012. La Plata, Argentina. La Plata: Facultad de Ciencias Naturales y Museo.

RODRIGUES, RR. and GANDOLFI, S., 2004. Conceitos, tendências e ações para a recuperação de florestas ciliares. In RODRIGUES, RR. and LEITÃO FILHO, HF. (Eds.). Matas ciliares: conservação e recuperação. 2nd ed. São Paulo: Fapesp. p: 235-247.

SOARES, JJ., SILVA, DW. and LIMA, MIS., 2003. Current state and projection of the probable original vegetation of the São Carlos region of São Paulo State, Brazil. Brazilian Journal of Biology $=$ Revista Brasileira de Biologia, vol. 63, no. 3, p. 527-536. http://dx.doi.org/10.1590/S1519-69842003000300019. PMid:14758712.

TAUK-TORNISIELO, SM., GOBBI, N., FORESTI, C. and LIMA, ST., 1995. Análise ambiental: estratégias e ações. Rio Claro: Centro de Estudos Ambientais-UNESP/Fundação Salim Farah Maluf/T. A. Queiroz, 381 p. 